\title{
Backbone or Helping Hand? On the Role of Information Systems and Non-systematic Information in Managers' Work
}

\author{
Cecilia Gullberg and Alf Westelius \\ University of Linköping, Linköping, Sweden
}

\author{
Cecilia.gullberg@liu.se; Alf.westelius@liu.se
}

\begin{abstract}
Information systems are often described as horizontal integrators, supporting and integrating core processes and providing vast amounts of real-time data in organisations. However, previous research indicates that managers use an "information mosaic" - a variety of pieces of information and information sources, rather than one centrally planned and unified information system - to control their work. In this paper, we explore recurring work activities among a number of managers with different responsibilities and the use of information associated with these activities. The purpose is to put the formal computerised information system into the context of the information mosaic, thereby providing insight into how formal information systems support and do not support these managers' work. Personnel responsibility is a uniting factor in the way these managers handle information and is an area where information systems seem to mainly support minor activities. Furthermore, the use of formal and informal information sources appears to be intertwined. The main contribution of this paper lies in charting managerial information behaviour in the light of technological development.
\end{abstract}

Keywords: information use, information sources, managerial work, management information

\section{Introduction}

This article seeks to contribute to the debate surrounding managers' use of information and information systems. The management information issue is a longstanding one and has been highlighted from various theoretical perspectives. One stream of research is directed towards developing systems and concepts that are often labelled Decision Support Systems (DSS), specifically designed to support managers' decision making. There is also a broader approach to how to inform managers, beyond specific decision situations; integrated, all-encompassing Enterprise Resource Planning systems (ERPs) have gained increased scholarly interest, in particular among management control researchers who try to understand how managers use such tools, which are often viewed as the backbone of organisations. Other scholars view manage-

Material published as part of this publication, either on-line or in print, is copyrighted by the Informing Science Institute. Permission to make digital or paper copy of part or all of these works for personal or classroom use is granted without fee provided that the copies are not made or distributed for profit or commercial advantage AND that copies 1) bear this notice in full and 2) give the full citation on the first page. It is permissible to abstract these works so long as credit is given. To copy in all other cases or to republish or to post on a server or to redistribute to lists requires specific permission and payment of a fee. Contact HPublisher@InformingScience.orgH to request redistribution permission. ment as a collective and less systematic accomplishment, characterised by interaction with others and a large degree of fragmentation. In line with this view, it has been suggested that managers utilise a wide variety of pieces of information - "the information mosaic" - to manage their work, rather than relying on a centrally planned and unified system (cf. 
McKinnon \& Bruns, 1992). Specific, observable, and sometimes soft pieces of information seem crucial in this mosaic, whereas formal information systems mainly serve as a helping hand (McKinnon \& Bruns, 1992; Preston, 1986; Simon, Guetzkow, Kozmetsky, \& Tyndall, 1954). Some organisational researchers claim that soft information and dialogue, rather than numbers and formalised data, should be important means of managing. Proponents of this view often underline the need to create mutual understanding of data and information. There are also organisational scholars who point out the symbolic and legitimising value of information, a standpoint that differs largely from the conventional idea that information is intended to improve decisions.

In sum, elucidating the management information issue from multiple perspectives appears fruitful in advancing our understanding of how managers become informed in the presence of new information technologies. This is a highly relevant question; according to Hall (2010), there is still a significant lack of studies on how managers actually use information. The purpose of this paper is to explore the work of a number of managers with different responsibilities and put formal information systems into the context of the information mosaic. In this paper, we want to return to the everyday contexts experienced by managers at lower organisational levels and start from their perspectives. Methodologically, the paper is the result of an iterative process between theoretical concepts and empirical findings (cf. Eisenhardt, 1989; Walsham, 1995), resembling a multi-grounded theory approach (Goldkuhl \& Cronholm, 2010). In order to extend the scope of previous research on managerial use of information (e.g., McKinnon \& Bruns, 1992; Preston, 1986; Simon et al., 1954), we have chosen to mainly focus on non-manufacturing organisations in the public and non-profit sectors. Furthermore, considering that industrial companies form an evermore minor part of working life in Sweden - industrial companies represented about $15 \%$ of Swedish companies in 2009 (Statistics Sweden, 2009, as cited in Ekonomifakta, 2010) - this sample also provides a cross section of Swedish organisations. Two questions will be addressed:

- How do managers acquire the information that they need in their daily work?

- What role do information systems play in this?

The organisation of this article is as follows. Firstly, we provide a theoretical background for understanding the many facets of managerial information behaviour. Secondly, we account for the method used in conducting this study. Then, we present the perspectives of fourteen managers in twelve organisations on information use in their everyday work, followed by a discussion of these findings in the light of the theoretical framework. Finally, we answer the two research questions by presenting our conclusions regarding managers' reliance on soft information retrieved in verbal interaction, the role of pre-understanding in interpreting information, and the complementarity of formal and informal sources of information. In conjunction with this, some avenues for further research are presented.

\section{A Framework for Exploring Managerial Information Behaviour}

In this section, a range of disciplines are presented that will be used to analyse the empirical data. The initial part constitutes a background to how managers could be expected to use information, both the systematic and non-systematic dimensions. The second and third parts present explicit categories of management and the use of information that we find useful for advancing our understanding of the role of formal information systems in a management context. 


\section{Managerial Communication and Information Behaviour}

Managers in general are often described as people who frequently interact with others, who attend numerous meetings, who make extensive use of soft information, and who build their own mental models of decision situations (Carlson, 1951; Kotter, 1982; Mintzberg, 1975). Furthermore, it has been suggested that managers want to have discussions and reach social consensus (McKinnon \& Bruns, 1992; Weick, 1995), and that decision making is a social process shaped by interaction with others, rather than an isolated managerial activity (Sayles, 1964, as cited in Stewart, 1999). Tengblad (2000) uses the term "management as a collective accomplishment" (p. 31) to illustrate the social dimension of managerial work. Similarly, Cohen (2009) underlines the sociology of the decision-making environment, i.e., the context of informing. Furthermore, organisations depend on the numerous minor decisions made on a daily basis by its lower-level employees, not just on the big strategic decisions (Kaplan \& Norton, 1996; Rohde, 2005).

Well in line with this image of managerial behaviour, McKinnon and Bruns (1992) suggest that managers utilise various types of information and sources of information - "the information mosaic" - to control their work. Previous research (Preston, 1986; Simon et al., 1954) demonstrates similar results; rather than relying on a unified information system, managers seem to prefer the visible and specific, retrieved in the day-to-day work through verbal reports and observations of operations. Yet, aggregated accounting information provides a sense of the business (McKinnon $\&$ Bruns, 1992), augments financial awareness (Simon et al., 1954), and indicates the net effects of various operative events (McKinnon \& Bruns, 1992: Preston, 1986; van der Weeken \& Wouters, 2002). In a similar vein, Davenport and Prusak (1997) take a broad view and include both formal and informal sources in their use of the term management information. Taking a more extreme position, other scholars maintain that managers should manage through dialogue and informal discussion in lieu of "managing by numbers" (Södergren \& Söderholm, 2001). While arguing that managers make little use of formal information systems and that managerial work cannot fully be supported by hard data, Daft, Lengel, and Trevino (1987) call for further research to determine whether this holds in settings where new media have been introduced. The question has also been raised by McKinnon and Bruns (1992) and Davenport and Prusak (1997), who conclude that little is known about how different types of technology affect information behaviour. According to Hall (2010), there is still a significant lack of studies on what information managers actually use. In particular, managers' use of accounting information must be seen in context, how it is used in relation to other types of information and beyond specific decision situations (Hall, 2010).

Since the 1960s at least, a considerable amount of research and systems development has been directed towards developing Decision Support Systems (DSS) to support decision making. From the start, interaction between user and computer-based models and data was an important part of the decision support systems concept, but the field has also come to contain work with a more narrow focus on the computerised parts of the system. Alter (2004) takes a broader approach and refers to both decision making and to sensemaking. Furthermore, Alter suggests that the term decision support system be replaced by "decision support within a work system", where decision support may be both computerised and non-computerised, in both a repetitive and non-repetitive business situation. Along the same lines, Skyrius and Bujauskas (2010) distinguish between simple and complex information needs. Simple needs are based on routine actions and could be solved by a single information source, possibly an information system. Complex needs, on the other hand, result from ill-structured situations and require the ability of the individual to evaluate and make sense, rather than the use of information systems (Skyrius \& Bujauskas, 2010). Some researchers distinguish between different levels of management; for example, van der Weeken and Wouters (2002) relate the use of operational information to lower level management and the use of financial information to higher level management. However, the importance of specific 
operational information in making sense of financial data is emphasised (van der Weeken \& Wouters, 2002). Therefore, distinctions between different levels may not always be useful. Similar thoughts about the importance of pre-understanding in making sense of specific pieces of information retrieved from a system have been expressed by Weick (1985) and Langefors (1995).

\section{Multi-perspective Management}

As indicated above, managers' use of information and systems should be seen in a wider context. One avenue is the development of multi-faceted information and control systems, such as the Balanced Scorecard, promoting the idea that managers need more data of different types to manage their organisations (Kaplan \& Norton, 1996; Olve, Petri, Roy, \& Roy, 2003). Along a different track, Preston (1986) concludes that informal aspects of information processes will persist in spite of formal information systems, and therefore the latter should complement rather than replace the former. Hence, the interrelated nature of information processes implies that there is limited use in studying any one aspect in isolation. Therefore, we have adopted the idea of management control as a package (Malmi \& Brown, 2008). Malmi and Brown (2008) argue that management control should be studied as a package in order to understand how different types of control, both formal and informal, operate together. We will not go into detail concerning the various parts of their framework, but rather just adopt the overriding idea and the term package.

Other attempts to "package" the concept of management control have been made. Simons (1995) underlines the need to broaden the notion of control and promotes a tool that has four distinct purposes: diagnostic (performance measurement), interactive (dialogue and debate to create learning and to challenge underlying assumptions), belief systems (values, inspiration, sense of direction), and boundary systems (standards, codes of conduct). Along the same lines, Brytting, Westelius, and Westelius (2008) argue that sustainable organisations should incorporate multiple perspectives, where rationality and authority need to be balanced by meaning and mutual care and recognition of the individual. Similarly, based on a case analysis, Alvesson and Kärreman (2004) challenge the idea that management control is mainly about performance measures, formal rules, and direct supervision guiding behaviour. They argue that organisations may not necessarily employ a dominant type of control (as has been suggested by, for example, Mintzberg, 1999). Instead, they suggest that technocratic control (plans, systems, and performance measures) and socio-ideological control (beliefs, values, and culture) could be interlinked rather than dichotomised. Furthermore, Alvesson's and Kärreman's findings indicate that some technocratic control systems, such as time reporting and elaborated HRM practices, mainly serve a symbolic purpose rather than produce the desired rational results. For instance, the HRM system intended to rank and distribute employees according to their competence does not appear to function with great precision in the company under study. However, it does serve as a motivator for working long hours and as a symbol of competence development.

Thus, many researchers have contributed suggestions for and descriptions of packages, combinations of practices, or perspectives that complement each other to form the basis for management. Some also point out how certain tools or systems can have different uses - some of them in practice diverging from the official ones. We now turn to different ways in which information can be used.

\section{Three Categories of Information Behaviour}

Three main categories of information use can be found in the management literature: information as a basis for understanding, information to influence others' behaviour, and information used for symbolic purposes. The three categories are described below and summarised in Table 1. 
Ansari and Euske (1987) apply a two-dimensional framework in order to provide a set of categories for the use of a cost accounting system in a public organisation. Their distinction between rational and natural, on the one hand, implies that information may not only serve as a basis for choice, such as resource allocation and simulation, but also as a means of influencing others, legitimising actions, and asserting self-interest. Their distinction between internal and external, on the other hand, refers to information used inside the organisation (managerial accounting) and information used to mediate the relationship with external stakeholders (financial accounting). The rational perspective thus implies that information is used to evaluate efficiency, either internally or externally (Technical-rational category). The natural perspective indicates that internally information is used to influence others' attitudes, justify actions, and centralise procedures (Socio-political category) and externally as a means of gaining legitimacy (Institutional category) (Ansari \& Euske, 1987). The latter conforms well with Feldman's and March's (1981) idea that the use of information constitutes a symbol of rationality and competent management.

Other scholars have made similar distinctions among various categories of information behaviour; Table 1 summarises the main points. Langley (1989) uses the term "Information" to illustrate the traditional purpose of information to actually bridge an information gap and reduce uncertainty about a matter. "Information" could also involve either confirming the validity of existing ideas, or pulse-taking in order to get a feel for the views of various members of the organisation (Langley, 1989), a purpose that falls within Ansari's and Euske's first category. "Communication" refers to a less open-minded search for information that aims to position oneself, justify action, or to convince others of what one already knows, while "Direction and control" implies the use of information to draw attention to problems and guide others to adequate action, for instance by demanding a report from a subordinate. Both "Communication" and "Direction and control" thus serve to influence others, which is a socio-political purpose (the second category) in Ansari's and Euske's terms. "Symbolic" refers to the use of information to display rationality, a purpose similar to Ansari's and Euske's third category. "Symbolic" also implies the signalling of participation and concern - a symbolic use inside the organisation (Langley, 1989). An example of symbolism at work is noted by Westelius (1996) in management accounting and control projects, where being included in or excluded from the information gathering affected people's attitude to and acceptance of the resulting management accounting and control principles.

Habermas' (1996) dimensions of communicative action could provide a more fine-grained tool for articulating the different roles that information may play from a management perspective. There are three types of actions that are particularly relevant to how managers use information. Understanding-oriented action is directed towards exchanging information about events and decisions to achieve mutual understanding among the actors involved, or at least to make them understand each other. This is similar to the traditional objective of information - reducing uncertainty (the first category). The purpose of success-oriented action, on the other hand, is to control or influence someone else, either in a direct, non-social manner by issuing an order (instrumental action) or in a more subtle, social mode by negotiation and discussion (strategic action) (Habermas, 1996). Thus, information exchange as a means of influencing others (the second category) can take different forms with varying degrees of sophistication.

Some researchers make a clear distinction between decision making (the first category) and control (the second category) and argue that management control research should focus on the latter, that is, how information is used to influence others' behaviour (Malmi \& Brown, 2008; Zimmerman, 2001). However, Malmi and Brown acknowledge the difficulty of such a distinction on the empirical level. For example, planning could serve both as a means of involving people in the organisation and as input for decision making (Malmi \& Brown, 2008). Langley (1989) also notes that different forms of use of information may intermix in practice. Habermas' (1996) distinction between understanding-oriented and success-oriented social action is not obvious; engaging in 
negotiation to achieve a certain goal could also provide the initiator with new information. The other way around, undertaking understanding-oriented social action may have the effect of influencing others, not just filling an information gap.

Table 1: Main categories of use of information

\begin{tabular}{|l|l|l|}
\hline $\begin{array}{l}\text { Reduce uncertainty, increase } \\
\text { understanding }\end{array}$ & $\begin{array}{l}\text { Influence others' behav- } \\
\text { iour }\end{array}$ & Symbolic \\
\hline $\begin{array}{l}\text { "Technical-rational" (Ansari \& } \\
\text { Euske, 1987) }\end{array}$ & $\begin{array}{l}\text { "Socio-political" (Ansari } \\
\text { \& Euske, 1987) }\end{array}$ & $\begin{array}{l}\text { "Institutional" (signal rationality) } \\
\text { (Ansari \& Euske, 1987; Feldman } \\
\text { \& March, 1981) }\end{array}$ \\
\hline "Information" (Langley, 1989) & $\begin{array}{l}\text { "Communication", } \\
\text { "Direction and control" } \\
\text { (Langley, 1989) }\end{array}$ & $\begin{array}{l}\text { "Symbolic" (signal rationality, or } \\
\text { participation and concern) } \\
\text { (Langley, 1989) }\end{array}$ \\
\hline $\begin{array}{l}\text { "Communicative action" (under- } \\
\text { standing-oriented, social) (Ha- } \\
\text { bermas, 1996) }\end{array}$ & $\begin{array}{l}\text { "Instrumental action" } \\
\text { (success-oriented, non- } \\
\text { social) } \\
\text { "Strategic action" } \\
\text { (success-oriented, social) } \\
\text { (Habermas, 1996) }\end{array}$ & \\
\hline
\end{tabular}

\section{Summary}

To sum up, we have adopted a multifaceted view of management control in order to capture both formal and informal practices, the use of both soft and hard information, and both unidirectional and multidirectional flows of information. Furthermore, we can expect information-based practices to materialise with various purposes, as can be seen in Table 1. In addition to its traditional purpose of providing a basis for measuring and following up and for reducing uncertainty, information can also serve to influence others' behaviour by drawing attention to problems or forming a basis for issuing an order or a basis for negotiation. As noted by some scholars, the role of information can also be mainly symbolic, in the sense that impressive plans and documents or cost accounting systems symbolise rationality and willingness to act, or that demanding information from others can symbolise participation and concern. Hence, three rough categories can be distinguished: information as a means of reducing uncertainty, information as a means of influencing others, and information as a symbol. In spite of some researchers' view that the first and the second should be clearly distinguished, we argue that they may merge or at least that the line in between is likely to be blurred at times.

\section{Methodology for Approaching the Managerial Information Environment}

As this study is explorative, we have gathered perspectives from a variety of managers rather than focused on one particular type of manager. This paper includes interviews with fourteen managers in twelve organisations and encompasses both the public, private and non-profit sectors. They were conducted in 2009. The responsibilities of these managers vary, e.g., some have personnel responsibility, some have financial responsibility, and some are also part of the organisation's operational activities and because of this are not full-time managers. It could be expected that the role of formal and informal information sources differ among them. This serves our purpose since we are interested in outlining both the formal and the informal dimensions of these managers' use of information, regardless of what sources of information that could be expected to be predomi- 
nant. The interviewees are listed in Table 2. Personnel and budget responsibility is highlighted in the third column. This is the result of both confirmed expectations and emerging ideas. From the start, budget responsibility was expected to direct focus to accounting information. As the study continued, personnel responsibility also turned out to be important for information behaviour. Initially, we strove to map differences among the managers but after some time we realised that there were also many similarities. After about ten interviews a clearer pattern emerged, and after fourteen interviews the material was deemed sufficient for the purpose of the study.

Table 2: List of interviewees

\begin{tabular}{|l|l|l|}
\hline Position & Organisation & Responsibility \\
\hline CEO & $\begin{array}{l}\text { Municipally-owned broadband and } \\
\text { infrastructure provider }\end{array}$ & Personnel, budget \\
\hline Vicar & Church & Personnel, budget \\
\hline Head of administration & Municipal environment department & Personnel, budget \\
\hline Administrative manager & University department & Personnel, budget \\
\hline Headmistress & Municipal school & Personnel, budget \\
\hline Headmistress & Private school & Budget \\
\hline Section manager & High-technology company & Personnel, budget \\
\hline Section manager & High-technology company & Personnel \\
\hline Operations manager & $\begin{array}{l}\text { Secretariat of a non-profit organisa- } \\
\text { tion }\end{array}$ & Personnel, budget \\
\hline Team leader & Call centre & Personnel \\
\hline Deputy operations manager & Private care provider & Personnel, budget \\
\hline $\begin{array}{l}\text { Project manager (former dis- } \\
\text { trict manager in the same com- } \\
\text { pany) }\end{array}$ & Grocery store chain & $\begin{array}{l}\text { Personnel and } \\
\text { mer position) }\end{array}$ \\
\hline Programme manager & University department & Budget \\
\hline Programme manager & University department & Budget \\
\hline
\end{tabular}

Building on Eisenhardt (1989), Walsham (1995) discusses three possible uses of theory in interpretative IS research: as an initial guide, as a part of iterative data collection and analysis, and as the final product of research. The first two are particularly relevant in this study. A few studies on how managers use information (e.g., McKinnon \& Bruns, 1992; Preston, 1986; Simon et al., 1954) form the core of this study and constitute an important knowledge basis for comparing present with previous information behaviour. In particular, McKinnon and Bruns (1992) provided useful guidance in conducting the interviews. However, as shall be seen in the following section, the empirical data is categorised according to empirically grounded patterns. Additional theories and concepts then served to identify and shed light upon interesting issues in the interviews. Conversely, having become more theoretically informed, new types of interview questions emerged. Hence, there was an iterative process between empirical data and theoretical concepts (cf. Eisenhardt, 1989; Walsham, 1995), similar to a multi-grounded theory approach (Goldkuhl \& Cronholm, 2010). A multi-grounded theory approach differs from the grounded theory approach in 
that the emerging concepts are not solely empirically grounded, but also contrasted with existing theory (Goldkuhl \& Cronholm, 2010).

The interviews were face-to-face (with the exception of one telephone interview), open-ended, and semi-structured. On average, the duration of the interviews was one and a half hours, ranging from fifty minutes to three hours. When necessary, follow-up questions were sent to the respondents via e-mail in order to clarify matters. In three cases, follow-up interviews were conducted. The interviews mainly focused on the major work activities of the respondent and the use of information associated with these. Questions were asked about the sources of information, system support, communication patterns, and lack of information. As will be seen below, the interviewees display both similarities and differences in their answers.

\section{Interview Results: Managerial Work Activities and the Use of Information}

The findings will be categorised in accordance with the major categories of work activities that were identified when interpreting the data. Although some activities may converge at times, we aim to create a comprehensible and transparent view of the work of these managers by clearly distinguishing among the activities below.

\section{Personnel Responsibility}

As shown in Table 2, most of our managers have responsibility for personnel, something which seems to be a uniting factor in their information behaviour. The project manager, the two programme managers, and the private school headmistress do not have responsibility for personnel. However, the project manager used to have such responsibility in his previous position as a district manager in the same company. There are two headmistresses at the private school, with different areas of responsibility, and therefore this headmistress does not have responsibility for personnel. The deputy operations manager of the care provider shares this responsibility with her manager, and the CEO of the municipally-owned broadband and infrastructure provider solely carries direct responsibility for two people; the additional people who work for him are externally hired consultants. The latter is the only interviewee who has not mentioned personnel issues as one of his three main work activities.

Personnel responsibility, in general, seems to involve activities such as human resource allocation among units, as well as among projects and tasks, and what some refer to as "personnel care." Many of these managers have expressed a wish to be visible and available and to give recognition to their co-worker, a desire which could be related to the latter activity. In order to allocate human resources, meetings with other unit managers or project managers, which allow for information exchange about competences and quantities needed and available, are necessary. Both section managers, although not working for the same company, have the impression that orders are often placed at short notice, and therefore they would like more continuous information from the sales side in order to be able to plan their human resources more long term. Furthermore, the annual career and salary meetings with subordinates provide the managers with information about their subordinates' needs, wishes, and future plans, something which is deemed useful when planning resource allocation. Some managers store such information in a documentation system. Moreover, more implicit information about their subordinates' well-being and abilities is needed, information that cannot be retrieved from formal systems. The operations manager stresses the importance of knowing how his subordinates feel and whether they have any problems in their private lives, in order not to put unnecessary pressure on someone in a difficult situation. He also wants to know what they think about his way of managing, so that he can develop his managerial competence. 
In addition to the more structured career and salary meetings, personnel responsibility also appears to require unstructured encounters. Some of the interviewees explicitly mention "I see you" meetings and the need to act as therapist: someone who listens to subordinates and asks them for information. It also seems important to ask subordinates for advice for the sake of involving them, for instance, about whether an electronic mail is clear and informative enough to send out to everyone. One manager, who is located in an open-plan office space, has the impression that she captures a lot of information on how work is progressing, or how busy certain people or teams are at the moment, by her mere presence. According to her, this is useful information for allocating human resources. The team leader, also located in an open-plan office, believes that overhearing is crucial in understanding her subordinates' education needs. Several other respondents also seem to be sufficiently close to their subordinates to sense how things are going. One manager browses the office in the morning to see whether they have started working, whereas another poses more direct questions on how work is progressing. Obviously, the performance of the subordinates is one important part of the information that these managers need.

Some of the managers note use of formal information systems as a minor complement to the performance information they pick up in interaction with their subordinates and by being close to them. One of the section managers was previously part of a larger section, but this was reorganised in order to create more transparency. The company in question uses pay-forperformance salaries, thus requiring the manager to have more insight into how his subordinates are working. He has access to a system with notes on salaries and previous career meetings that he uses for the salary meetings. The other section manager follows a thorough routine when evaluating her subordinates; a project manager, a team leader, and another colleague of the subordinate's choice are asked to comment on the individual's performance. The same manager can access a system that allows her to see average and median salaries in the company in the region when preparing for the salary meetings. The team leader can retrieve information from the telephone system about whether the subordinates respond to phone calls and how lengthy the phone calls are. She believes that such information can be useful to some extent, but that it must be complemented by real-life impressions of how the subordinates function.

\section{Financial Responsibility}

As demonstrated in Table 2, not everyone has financial responsibility, and not all of those who do mention it among the three main activities in their work. Moreover, the two headmistresses and the municipal environment department manager have administrators to help them. Generally, transaction-handling systems and invoice systems appear to be the formalised systems at their disposal. A number of the respondents with financial responsibility can access and follow up financial performance via a web-based system. The private school headmistress receives an electronic report "not more than once a month." In case of deviations from budget, she is contacted by the administrators. She would like more continuous feedback on the financial performance, although it "seems to work anyway."

Our interviewees seem to prepare the budget in slightly different manners. The municipal school headmistress claims to have limited scope for change in her budget. It is mainly based on historical information, and the fixed costs are already determined. Therefore, she only allocates financial resources among the teaching activities, and, due to limited resources, there is little room to engage in creative dialogue with the teachers. On the other hand, the operations manager initiates discussion with his subordinates, whom he believes are more knowledgeable on their activities than he is, in order to generate ideas about what they should focus on during the coming year. He asks them to identify what signals they obtain from outside the organisation, from competitors, from members, etc. within the different fields of activities. This information assists him in establishing the budget. The vicar also involves her subordinates in the budgetary work, yet it seems to 
follow previous budgets to a fairly large extent. Instructions from the church council also play a part in establishing her budget. The environment department manager asks his subordinates to prepare a SWOT analysis in order to supplement the yearly plan, but he also declares that he looks at previous plans to a large extent.

The two programme managers both attempt to respond to problems in their respective programmes when allocating financial resources among the courses. By means of regular dialogue with teachers and students, they obtain a sense of whether an additional seminar is needed in a course, for example. The number of students who have chosen each course is vital information in allocating financial resources, and this can be obtained by the secretary from the study administrative system. However, one of the programme managers mentions that the system is not entirely reliable; students change their mind regarding optional courses, or they decide to study some of the courses in a different order than the usual. Therefore, in addition to the information retrieved from the system, he needs to speak to the secretary or to the students directly in order to obtain a more valid picture of how many students can be expected to attend certain courses during the year. The CEO, on the other hand, believes that he is well aware of the financial dimension of his work. While costs are relatively stable and possible to follow in the invoice system on a regular basis, revenues are not. However, he knows intuitively what the revenues will add up to by the end of the year because he does a follow-up on sales every week. For this purpose, he uses a rudimentary Excel-based system, fed by the sales people with information such as which potential clients have been contacted and how many deals have been closed.

\section{Coordination}

Closely related to the allocation of human and financial resources is the activity of "general coordination" that can be seen in some cases. One of the programme managers mentions "coordination - making things work" as a primary activity, which includes designing the programme with courses in appropriate order. To this end, he searches for signals from students and teachers, both through structured and unstructured meetings and through the course evaluation system, about what is working and what is not working in the programme. Furthermore, he obtains useful information from the Faculty about "what is going on": for example, policies, and new administrative routines. A few times each year, programme managers from different universities meet and discuss common issues and possible solutions to these, which is also useful input to the general coordination of the programme.

Supporting projects is one main work activity according to one of the section managers. When approaching a delivery deadline, she enters a system that signals "red" or "green" to indicate the status of the different parts of the product, e.g., how many times it has been tested. In case of green light, there is little need to approach the subordinates involved in the project, although she mentions that she must approach some people more than others because of the product's complexity or because of the individual's capacity. However, most of the project work is dealt with through weekly meetings; she even refers to a "meeting disorder" in the organisation - too many meetings. There are generally three projects running in parallel, which implies one weekly meeting for each project. During these meetings the project status is reported, potential problems are highlighted, and they discuss how the line organisation can support the project. There is an intranet where agendas of future meetings are announced. She believes this is useful because it enables her to prepare and to decide whether she must attend a meeting or not.

The private school headmistress spends a considerable amount of time organising and scheduling the teaching. Because she has not yet learnt to fully operate the scheduling system, she uses postits and seems to keep a lot of information in her head. To schedule the teaching, she needs to know "who does what," who is on parental leave, who works part time, who wants to leave work earlier which days of the week, the availability of the sports arena, and also possible wishes from 
the pupils. Information about the sports arena is found in a system shared with another school. She gathers the rest of the information from people in the organisation, either by electronic mail or by personal meetings. She believes that the pupils' wishes may be channelled through the teachers. With regard to more important matters, they have formal meetings, but most matters are solved via informal encounters. In addition to scheduling, she is faced with other problems, such as pupils with special pedagogical needs or deficiencies in the pupils' work environment, issues that also appear to be addressed by spontaneous meetings with colleagues. She experiences a lack of information about rules and regulations. She used to work for a municipal school, where such information was more easily accessible thanks to the municipal legal advisor.

In the case of the municipally-owned broadband and infrastructure provider, there is one central web-based documentation system that contains information about clients, services, pipes, and fibres. According to the CEO, this is the heart of the organisation, although he consults it only occasionally when clients address him directly and want to know about the location of fibres. Rather than a management tool, it seems mainly to be a means of coordination among his coworkers. Indirectly, it could be regarded as a management tool because it enables the co-workers to manage on their own. The CEO appears to achieve coordination and control by weekly meetings where they discuss what is going on in general. He is of the opinion that these meetings are useful in providing him with a continuous overview of possible problems.

\section{The Strategic Outlook}

Only two interviewees, one of the programme managers and the vicar, explicitly mention the strategic dimension of their work among their main activities. However, the vicar does not appear to fully take on a role as strategic manager after all; when asked what kind of information she uses to formulate strategies, she refers to the instructions and guidelines provided by higher levels in the national organisation. The CEO expresses a wish to know more about the future and about the competitive situation. He participates in strategy meetings with the board, and he appears to have a strategic perspective on the business. However, he does not mention strategy as one of his main work activities. In the programme manager's view, designing the programme in a strategic manner, along with promoting it both externally and internally, constitute some of his major work activities. In order to handle this, he gathers information about the competitors via their web pages, he organises focus groups and questionnaires directed to the existing students, and he engages in dialogue with the unit managers included in his programme. He also browses the web pages of the units. Furthermore, he wants to map what the students on his programme have learnt, why they chose this particular programme, and how he can profile the programme according to the pedagogical and research competences that are available in the different units. He also wishes to find out how similar programmes at other universities are designed, either to generate new ideas or to confirm existing ones. He seems to be mainly concerned about the competitive situation, although contacts with other universities may also concern an exchange of ideas in order to solve mutual problems. The other programme manager expresses it instead as "coordinating the programme, making things work." To him, this also involves extensive dialogue with course directors and unit managers, but unlike the first programme manager he does not seem to have an external outlook. Both of the programmes are roughly equal in terms of competitive situation.

The deputy operations manager of the care provider mentions dealing with customers as one important part of her work. This appears to include both managing complaints and planning what resources to allocate to a certain customer, together with more outward-looking activities such as organising events for elderly people in the local area and providing information about the right that individuals have to choose their care provider. Hence, she does not have a clearly strategic focus on the customers. According to her, information about the competitors is not gathered at this level, but at higher levels in the organisation. She appears to be mainly concerned with in- 
formation about what is happening with the clients, whether someone's state of health is changing, and whether the client needs additional help. This kind of information serves as a basis for the invoices, and therefore it is imperative that the employees report any changes in the work with the clients. Such changes seem to be reported to the manager through informal meetings in her office, but also via the two coordinators in the organisation. Furthermore, she meets regularly with a group where deviations from quality standards are discussed; these meetings also serve to indicate whether some clients need more help. The coordinators plan all the activities and are responsible for the telephone service. Hence, they receive large amounts of information and capture things that the managers are not aware of. The deputy operations manager meets with the coordinators on a regular basis, both in a structured and in an unstructured manner.

Not surprisingly, the strategic dimension implies a lack of information to some. As indicated above, the CEO would like more information about what is going on in the industry, the competitive situation, and about EU policies. He believes that revenues are characterised by a high level of uncertainty. The more strategically oriented programme manager expresses a wish to know more about the students' careers after graduating, in order to more effectively promote the programme both to existing and potential students. Several managers wish for information from higher level management about "what is going on." Knowing about future plans and possible organisational changes earlier, and reasons for these, would help them to better inform their subordinates. At the call centre, an intranet is used to communicate some of the latest information.

\section{Quality Management}

Among the interviewees, it is the project manager at the grocery store chain who appears to be the most frequent user of financial information. He uses it for quality management purposes. He has no budget responsibility, but he uses such information to trace unnecessary costs and deviations that could in turn generate ideas about efficiency improvements. The tracing of financial information is usually followed by investigation of the matter, e.g., he approaches the store managers or he visits the store in question to investigate how they work and to see whether improvements could be made. Furthermore, he calculates how much a store with a certain number of customers should consume in terms of trucks, trolleys, and cleaning machines. These economic figures serve as arguments when implementing the changes, although he stresses the importance of "knowing the business." Hence, in order to make sense of the economic information, he needs to understand the operational dimension. He emphasises that his previous experience as a district manager in the same company is crucial, along with finding the right persons that could help him to convey a message of cost effectiveness.

One of the interviewed section managers is also responsible for similar process development tasks. In this case, it is done by discussion with the subordinates and with other section managers. He wants to know how they work, e.g., how much time is spent on a task, the order in which tasks are done, or where work is stored (everyone is expected to store their work on a shared disk, but some use private storage instead), and why they work in a certain manner. These discussions seem to involve many strong wills.

The deputy operations manager points out that quality management is one of the major activities in her work. Everything that deviates from what is considered "normal" is reported through a paper-based system. Deviations for instance include errors in providing clients with medicine, a client who has fallen repeatedly, or someone who has forgotten to sign the medicine list. A special form is filled in explaining what has happened, reasons for the deviation, measures that have been taken, and measures that could be taken in the long term. These forms are then dropped into the manager's and the deputy manager's post boxes. Once a month, the quality group meets and discusses the deviations. 
The CEO regularly engages in discussion with the contractors in order to improve quality and to reduce costs. As mentioned above, he has weekly meetings with his co-workers where problems can be raised. The minutes of these meetings serve as a basis for biannual quality meetings with the contractors. Probably, several others of our respondents are concerned with quality and process development, yet perhaps to a lesser extent in their daily work, and they do not mention it in the interviews.

An overview of the interviewees' mention of use of information systems can be seen in Table 3 .

Table 3: Interviewees' mention of use of IS

\begin{tabular}{|c|c|}
\hline Position & Interviewees' mention of use of IS \\
\hline $\mathrm{CEO}$ & Accounting, invoice, documentation \\
\hline Vicar & Documentation \\
\hline Head of administration & Accounting, invoice, documentation \\
\hline Administrative manager & Accounting, invoice, documentation \\
\hline Headmistress - municipal school & Accounting \\
\hline Headmistress - private school & $\begin{array}{l}\text { Scheduling, accounting (indirect use through } \\
\text { accountant), room booking }\end{array}$ \\
\hline Section manager - company 1 & $\begin{array}{l}\text { Accounting, invoice, documentation, shared } \\
\text { disk for work-in-progress }\end{array}$ \\
\hline Section manager - company 2 & $\begin{array}{l}\text { Automatic software build system, documenta- } \\
\text { tion, salary statistics, intranet }\end{array}$ \\
\hline Operations manager & Accounting, documentation \\
\hline Team leader & Documentation, intranet, telephone system \\
\hline Deputy operations manager & $\begin{array}{l}\text { Paper-based quality follow-up (not computer- } \\
\text { ised, but systematised), documentation, intranet }\end{array}$ \\
\hline $\begin{array}{l}\text { Project manager (former district manager in the } \\
\text { same company) }\end{array}$ & Accounting \\
\hline Programme manager 1 & $\begin{array}{l}\text { Web pages, study administrative system (indi- } \\
\text { rect use through administrator) }\end{array}$ \\
\hline Programme manager 2 & Course evaluation system \\
\hline
\end{tabular}

\section{Discussion}

The interview results will now be discussed in the light of the perspectives on management control and use of information presented in the theoretical framework. The discussion is structured around a few core themes that emerged when interpreting the empirical data.

\section{The Importance of Soft Information and Personal Meetings}

A common trait among many of the interviewees is that they frequently attend meetings, both formal and informal, regardless of work activity. This provides support for the commonly expressed idea that oral information exchange is of great importance to managers (e.g., Carlson, 1951; Kotter, 1982; McKinnon \& Bruns, 1992; Mintzberg, 1975). However, verbal interaction 
seems to be of particular importance to those who have responsibility for personnel. In fact, our respondents with responsibility for personnel display a number of common traits. Most of them seem to cherish the soft and sometimes even implicit kind of information that they acquire through direct conversation with their subordinates. Obtaining a sense of their needs, career wishes, attitudes, and abilities, and how their work is progressing appears to be one of their most important tasks. They also seem to need clearly explicit kinds of information, such as competences and work hours needed in different projects or units, in order to allocate their human resources. However, this neither makes them rely on, nor wish for, multi-faceted Balanced-Scorecard-like systems (challenging the general applicability of proposals by Kaplan and Norton, 1996, and Olve et al., 2003). Most of this information is instead gathered through personal meetings, both formal and informal, such as yearly career development meetings, regular meetings with project managers and other managers, unstructured encounters in the corridor, or, for those located in open plan offices, by overhearing.

Both the explicit and implicit kinds of information mentioned above serve the purpose of reducing uncertainty (First column in Table 1; Ansari \& Euske, 1987; Habermas, 1996; Langley, 1989) regarding running and evaluating the unit and creating mutual understanding between the manager and the employee about the work situation. However, gathering information about how the subordinates feel about different matters could be a sign of concern, thus also serving a more symbolic use of information (Third column in Table 1; Langley, 1989). Some interviewees have explicitly highlighted the symbolic importance of "I see you" meetings, or being a "therapist;" hence, information exchange is not just for strictly task-related reasons but also a means of acknowledging their co-workers. This symbolic use of information concerns the inside of the organisation; the symbolic value does not lie in displaying rationality towards external stakeholders (cf. Ansari \& Euske, 1987). The value of operative and soft information is frequently mentioned in previous studies on managerial use of information (McKinnon \& Bruns, 1992; Preston, 1986; Simon et al., 1954), but rarely, as in this study, in relation to personnel issues.

Furthermore, as mentioned earlier, personnel responsibility seems related to a wish to be visible and available. This could perhaps explain why these managers frequently engage in direct, verbal communication with their subordinates. With regard to personnel responsibility-related activities, formal information systems seem to mainly be used for documentation purposes, in order to remember information required in less frequent situations. Possibly, both managers and subordinates wish to form part of a social context; as suggested by Brytting et al. (2008), mutual care forms a vital element in sustainable organisations. Moreover, being in closer contact with the subordinates may allow for a more informed judgement of their work performance. The close contact could probably serve all three purposes of use of information (Table 1; Ansari \& Euske, 1987; Feldman \& March, 1981; Habermas, 1996; Langley, 1989): a basis for deciding about career promotions and salary raises, or simply about project status; a means of exercising control; and a way of signalling care, and that career- and salary-related decisions are made according to principles of fairness. Unlike Alvesson and Kärreman (2004), we do not detect use of HRMrelated information systems that generate effects in subordinates' work patterns. Instead, in our study, personnel responsibility frequently results in two-way communication that resembles $\mathrm{Si}$ mons' (1995) interactive control, partly because the information comes from the actual individuals, and partly because of the symbolic and the social value of the interaction.

Verbal interaction also frequently occurs in conjunction with other activities, such as coordination and quality management. In the case of the section manager who engages in discussion with colleagues in order to identify and capture the complexity of quality-related problems, it appears to be a complex information need (Skyrius \& Bujauskas, 2010) where a formal information system may not be of great help. These discussions appear to fulfil the purpose of reducing uncertainty (First column in Table 1; Ansari \& Euske, 1987; Habermas, 1996; Langley, 1989), but possibly 
also have the potential of serving a symbolic purpose (Third column in Table 1; Langley, 1989), in the sense that subordinates are being asked to provide their manager with valuable information. Such inclusion could make the subordinates more prone to accept management decisions (cf. Westelius, 1996). Yet, it could also give the subordinates the impression that they are being controlled; some of them seem reluctant to store information on shared disks and may, therefore, not be delighted when asked to account for their work methods. There is probably a fine line between displaying concern in a symbolic manner and asking for information to exercise control, and the adequate degree of transparency should be considered.

As for coordination in general, verbal interaction seems to fulfil both simple and complex information needs (cf. Skyrius \& Bujauskas, 2010). Sometimes, meetings are used to discuss and explain matters (complex information needs), yet sometimes, verbal interaction occurs spontaneously in the corridor or in the open-plan office space, and rather serves to exchange information in a straight-forward manner (simple information needs).

\section{Complementarity of Formal and Informal Sources of Information}

Even though formal information systems play a minor role in the above-mentioned activities, they do play a role in the total information mosaic, in particular in the financial dimension of these managers' work. Here, formal information systems play a significant role in following up and keeping track of financial performance once the budget is established, i.e., in the diagnostic control (Simons, 1995). However, preparing the budget usually requires extensive dialogue with colleagues about what should be done during the coming year, in addition to looking back on historical information. This is well in line with the interactive control promoted by Simons (1995). There is one exception to this: the municipal headmistress who is under severe economic constraints. She treats allocation as a one-man decision, which resembles instrumental action (Habermas, 1996) and the authoritative dimension of management (Brytting et al., 2008). Some of the managers claim that the subordinates are more initiated into what is going on, and consequently the dialogue preceding the budget has the potential of actually rendering the managers more informed (First column in Table 1; Ansari \& Euske, 1987; Habermas, 1996; Langley, 1989). The subordinates may have ideas and opinions that are valuable to the manager, either because they are closer to the business or because they are specialised in a certain area. In some other cases, it is not clear whether the subordinates are more well-informed, or that their opinions are even taken into account, but involving them in the annual planning could serve a symbolic purpose (Third column in Table 1; Langley, 1989), or a control purpose (Second column in Table 1; Ansari \& Euske, 1987; Habermas, 1996; Langley, 1989). As has been demonstrated by Westelius (1996) and suggested by Malmi and Brown (2008), planning is an example of a management control practice that could serve both as input to decision making and as a way of influencing others by developing acceptance for the plan and the budget. In both cases, formal and informal information sources appear to complement each other.

The complementarity of formal and informal information sources is also clearly displayed in the case of the programme manager who cannot fully trust the information retrieved from the university administrative system. In order to obtain a more accurate picture of how the students will be distributed, he turns to an informal source, although the administrative system is valuable initially. The total picture is then used as a basis for establishing the programme budget. Another example is the team leader, who believes that the balance between computerised information and real-life impressions of the subordinates is important when evaluating their performance. Similarly, one of the programme managers combines information from the course evaluation system with meetings with colleagues and students to make things work within the programme. 


\section{The Role of Pre-understanding in Making Sense of Information}

To some extent, the idea of complementarity borders on the role of pre-understanding in interpreting information. Some interviewees emphasise that previous experiences are crucial in making sense of the information retrieved, the most obvious example being the project manager. To him, financial information in a formal system is of daily importance and crucial in identifying potential problems related to work methods. This is similar to Simons' (1995) diagnostic control. However, this is supplemented by direct observation and discussion in the stores in order for him to capture a sense of how work is conducted. The information in this case thus appears to initially inform the project manager to a large extent. Furthermore, his previous experience as a district manager guides him in terms of what the work processes in the stores look like and whom to contact in what matter. The former aids in making sense of the information retrieved from the system, whereas the latter, more interactive control (Simons, 1995) particularly facilitates when he attempts to sort things out and check for possible reasons for a certain deviation in the financial information. Again, formal and informal sources of information serve to complement each other. This also supports Hall's (2010) proposition that accounting information can evoke verbal discussion and that managers use verbal communication to make sense and create a context to the information. This case clearly illustrates the role of pre-knowledge in drawing inferences and acting upon the information retrieved (cf. Langefors, 1995; Weick, 1985).

Furthermore, the project manager uses the financial information to form arguments for implementing changes to a work process, that is, to exercise control and influence others' way of thinking (Second column in Table 1; Ansari \& Euske, 1987; Habermas, 1996; Langley, 1989). Whether such action is viewed as instrumental or strategic (Habermas, 1996) probably depends on the degree of discussion that follows his presentation of economic data. Since he emphasises the importance of finding the right people that can help him to convey a message about cost effectiveness, there is reason to believe that there is rather limited room for discussion and negotiation with those who are to realise the changes. Therefore, it could probably be considered instrumental rather than strategic action. His information behaviour reflects a more authoritative dimension of management (cf. Brytting et al., 2008). The emphasis on trying to convey an overarching ideal of cost effectiveness and the direct intervention when he detects inefficiencies could be seen as attempts to implement both belief systems and boundary systems (Simons, 1995).

One of the section managers constitutes another example of the importance of pre-understanding (cf. Langefors, 1995; Weick, 1985). Even though she can access information about the quality of the product in a formalised system, she cannot fully make use of it unless she has information about the complexity of the product and about the individuals involved in producing it.

\section{Formal Information Systems and Lack of Information}

Deficiencies in management information are often associated with formal information systems; in particular, accounting information systems are considered to provide information too late, with too high levels of aggregation (cf. McKinnons \& Bruns, 1992; Preston, 1986; Simon et al., 1954). In this study, however, complaints about insufficient information are rarely related to formal information systems. Except for the private school headmistress, none of the interviewees complain about the accounting information in their work. Although not complaining about it, the CEO believes that accounting information generally confirms what he already knows. This is very much in line with McKinnon and Bruns (1992) and van der Veeken and Wouters (2002), who suggest that direct observation and other operational signals may serve as more useful information in the short run. The fact that financial responsibility does not interfere directly with daily activities and that operational information is often very timely also confirms that accounting information constitutes a relatively minor part of the information mosaic (cf. McKinnon \& Bruns, 1992). 
Some managers complain about a lack of information regarding organisational changes - information that they would like to pass on to their subordinates - which indicates that this lack compromises the authoritative role (Brytting et al., 2008) they want to fill. The strategic dimension of these managers' work is an area where a lack of information clearly can be seen, e.g., possible changes on the market. By its very nature, the strategic outlook implies a complex rather than a simple information need (cf. Skyrius \& Bujauskas, 2010), and, consequently, formal information systems should merely be able to support a minor part of it. Except for the competitors' web pages, future-oriented market information is not necessarily to be found in formalised systems and may not even be easily traceable at all. Web pages constitute a new means of keeping track of the competitors, compared to previous studies. Both of the section managers complain about orders being placed at short notice - an actual information gap (First column in Table 1; Ansari \& Euske, 1987; Habermas, 1996; Langley, 1989) that impedes their allocation of human resources. In contrast to the lack of strategic information discussed above, this resembles a simple information need rather than a complex need (cf. Skyrius \& Bujauskas, 2010). Here, a more systematic way of indicating how things progress on the sales side would probably be useful. Furthermore, it appears possible to address, since it should be easier to transmit internal signals than to provide external signals.

\section{Information Behaviour - Context Dependent or a Matter of Individual Perceptions?}

In contrast to previous studies (McKinnon \& Bruns, 1992; Preston, 1986; Simon et al., 1954), this paper mainly addresses the management information issue in non-manufacturing settings. Although numerous similarities can be seen between this study and previous ones, e.g., the degree of verbal communication and interaction with others and the extensive use of operational and soft information, differences have also been noticed. While information behaviour in manufacturing settings often revolves around quantities and more visible signals such as inventory levels or machines running, this study has identified subtler signals such as competences and employee wellbeing that seem to be of importance. Perhaps such information is deemed more important in a setting where knowledge rather than capital forms the basis of the activities (cf. Södergren \& Söderholm, 2001).

As has been illustrated in the discussion, despite the different contexts they find themselves in, our interviewees show some similarities. However, the two programme managers display little resemblance concerning their information behaviour, even though they could be expected to face fairly similar work contexts. One of them organises focus groups and questionnaires and browses the competitors' web pages. This information appears to have the purpose of increasing understanding and reducing uncertainty (First column in Table 1; Ansari \& Euske, 1987; Habermas, 1996; Langley, 1989). Well in line with the concept of professional bureaucracy (cf. Mintzberg, 1999), the programme managers are likely to have a substantial degree of freedom, which was also highlighted by one of them. This freedom, along with the absence of personnel responsibility, probably results in a more moderate use of information for control and symbolic purposes (Second and third column in Table 1) vis-à-vis the people who man the program, compared to some of the other interviewees. The other programme manager does not try to obtain similar input to any significant degree, an interesting finding that indicates that people in very similar positions may perceive their work roles fairly differently. Their role perception, in turn, results in different uses of information.

Perception of one's working role may also explain why some managers experience no lack of information in their work. Considering that few managers point to an actual overload of information or an excessively demanding work situation, this rather limited interest in additional information is an interesting finding. Alter (2004) suggests that future research should focus on the ef- 
fects of individuals' background, assumptions, and personality traits on decision making and sensemaking. Based on our observations, we believe that the idea of role perception would be useful in such attempts at advancing understanding of information behaviour.

Important points from the discussion are summarised in the appendix. Paraphrases from the interviews are used to illustrate the main conclusions of this paper.

\section{Conclusions}

We will now return to the research questions outlined in the introduction of the paper. How do managers acquire the information that they need in their daily work and what role do information systems play in this? Based on interviews with 14 Swedish lower-level managers in a crosssection of Swedish organisations, our findings demonstrate that the role of formal information systems as a backbone in organisations is not always obvious. This paper contributes to the debate on managerial information behaviour and puts formal information systems into context in the light of technological advances. By exploring information behaviour in various dimensions, we advance understanding of how formal information systems support and do not support managerial work. Despite considerable advances of the use of IT in society and in quotidian working life, managerial information behaviour in this study proves, with few exceptions, to be largely nonformal and based on interaction with people rather than computerised information systems.

In line with previous studies, managerial information is to a large extent acquired informally through personal contacts. Soft and operational information provide vital cues in the daily work, partly because their high degree of timeliness. Formalised systems do support some of the managerial activities discussed in this paper, yet their use is typically supplemented by less formal sources of information. Intranets and web pages are newcomers in the information mosaic compared to previous studies. However, they are not the major pieces. These managers seem to cherish soft kinds of information that cannot necessarily be easily structured in formalised systems. Furthermore, lack of information is mainly connected with more complex issues related to the future, either to what will occur inside the organisation or to possible changes on the market and to the subordinates' feelings and opinions. Such information could only to some extent be retrieved from formal systems. It appears that non-manufacturing settings create slightly different information needs compared to a manufacturing environment, e.g., more subtle signals about the people in the organisation. In particular, personnel responsibility appears to influence how managers acquire information, and there seems to be an act of balance between being a caring manager and being authoritative.

Information is often acquired through interactive dialogue to obtain a sense of how the subordinates think, although sometimes there is a more diagnostic use of information. A number of categories of information use have been identified in the management and accounting literature, among which bridging an actual information gap is only one of several purposes underlying managers' behaviour. These different uses are also noticeable in our study, where information behaviour variously, and often intermixed, serves to issue an order, initiate discussion, or display participation and concern for the subordinates. Those who feel strongly constrained by economic demands or the expectations of running a profitable business appear to engage less in symbolic dialogue and more in directive communication. In contrast to some previous studies, we find no explicit efforts to signal rationality by the use of formal information systems. However, symbolic efforts are seen in terms of displaying concern towards co-workers. Thus, even at the low-level managerial positions in this study, managerial information behaviour appears to be influenced as much by the signals the manager believes the behaviour sends as by the information needs it fills for the manager. The role of formalised systems in such displays is not directly noticeable, although such systems could possibly provide signals that result in contact with the subordinates. However, approaching subordinates directly and observing their work is probably more conven- 
ient and logical to a manager who is close to the daily operations and whose span of control is moderate. "Managing by numbers" is likely to be done on higher levels in the organisation.

In this article, we have highlighted the significance of pre-knowledge and informal dialogue in interpreting and acting upon information. Without dialogue and discussion, information retrieved from formal systems could result in a divergence of behaviour. Future research should seek to address how formal and informal information interact and translate into thoughts and action and what kinds of discussions arise from or call for the use of, e.g., a report. Is it about interpreting the data? Challenging assumptions? Reaching consensus? Taking concrete action? Understanding in more detail how formal and informal information interact should have implications for how management information and control systems are designed. As has also been discussed, differences in individuals' pre-knowledge generate disparate role perceptions, even in the same organisation. For example, people in the same position acknowledge the strategic dimension of their work to varying extent, which leads to rather diverging information needs. While one seeks out Business Intelligence-oriented information about clients and competitors, the other is more focused on practical coordination through day-to-day discussions with colleagues. Therefore, we believe that the concept of role perception, rather than just role, could help advancing our understanding of how various actors select information to handle their work. This also touches upon what constitutes strategic information; it is usually associated with higher level management and analytical tools, but what are the strategic issues of lower level managers? The Balanced Scorecard promotes the idea of visualising strategic intentions throughout the organisation, implying that a set of information could clearly be strategic also on lower levels. Investigating how strategic intentions come alive in day-to-day work through the combination of various types of information should also constitute an interesting avenue for future research.

\section{References}

Alter, S. (2004). A work system view of DSS in its fourth decade. Decision Support Systems, 38(3), 319327.

Alvesson, M., \& Kärreman, D. (2004). Interfaces of control. Technocratic and socio-ideological control in a global management consultancy firm. Accounting, Organizations and Society, 29(3-4), 423-444.

Ansari, S., \& Euske, K. J. (1987). Rational, rationalizing, and reifying uses of accounting data in organizations. Accounting, Organizations and Society, 12(6), 549-570.

Brytting, T., Westelius, A., \& Westelius, A-S. (2008). Meaning, authority, rationality and care as "MARCs" of sustainable organisations. Proceedings of the 2008 Annual Australian and New Zealand Academy of Management Conference, Auckland, New Zealand, 17 p.

Carlson, S. (1951). Executive behaviour. Stockholm: Strömbergs.

Cohen, E. B. (2009). A philosophy of informing science. Informing Science: The International Journal of an Emerging Transdiscipline, 12, 1-15. Retrieved from http://www.inform.nu/Articles/Vol12/ISJv12p001-015Cohen399.pdf

Daft, R., Lengel, R., \& Trevino, L. (1987). Message equivocality, media selection, and manager performance: Implications for information systems. MIS Quarterly, 11(3), 355-366.

Davenport, T., \& Prusak, L. (1997). Information ecology - Mastering the information and knowledge environment. New York: Oxford University Press.

Eisenhardt, K. M. (1989). Building theories from case study research. The Academy of Management Review, 14(4), 532-550.

Ekonomifakta. (2010). Statistics on Swedish companies according to industry. Retrieved October 11, 2010, from http://www.ekonomifakta.se/sv/Fakta/Foretagande/Naringslivet/Foretag-per-bransch/ 
Feldman, M. S., \& March, J. G. (1981). Information in organizations as signal and symbol. Administrative Science Quarterly, 26(2), 171-186.

Goldkuhl, G., \& Cronholm, S. (2010). Adding theoretical grounding to grounded theory: Toward multigrounded theory. International Journal of Qualitative Methods, 9(2), 187-205.

Habermas, J. (1996). Kommunikativt handlande - Texter om språk, rationalitet och samhälle [Communicative action - Texts on language, rationality and society]. Göteborg: Daidalos.

Hall, M. (2010). Accounting information and managerial work. Accounting, Organizations and Society, 35(3), 301-315.

Kaplan, R., \& Norton, D. (1996). Using the balanced scorecard as a strategic management system. Harvard Business Review, 74(1), 75-85.

Kotter, J. P. (1982). What effective general managers really do. Harvard Business Review, 60(6), 156-167.

Langefors, B. (1995). Essays on infology. Lund: Studentlitteratur.

Langley, A. (1989). In search of rationality: The purposes behind the use of formal analysis in organizations. Administrative Science Quarterly, 34(4), 598-631.

Malmi, T., \& Brown, D. A. (2008). Management control systems as a package - Opportunities, challenges and research directions. Management Accounting Research, 19(4), 287-300.

McKinnon, S., \& Bruns, W. (1992). How managers get the information they really need - The information mosaic. Boston: Harvard Business School Press.

Mintzberg, H. (1975). The manager's job; Folklore and fact. Harvard Business Review, 53(4), 49-61.

Mintzberg, H. (1999). Structure in fives: Designing effective organizations. Englewood Cliffs, NJ: Prentice-Hall.

Olve, N-G., Petri, C-J., Roy, J., \& Roy, S. (2003). Making scorecards actionable - Balancing strategy and control. London: John Wiley and Sons.

Preston, A. (1986). Interactions and arrangements in the process of informing. Accounting, Organizations and Society, 11(6), 521-540.

Rohde, F. (2005). Little decisions add up. Harvard Business Review, 83(6), 24-26.

Simon, H. A., Guetzkow, H., Kozmetsky, G., \& Tyndall, G. (1954). Centralization vs. decentralization in organizing the controller's department. New York: Controllership Foundation.

Simons, R. (1995). Control in an age of empowerment. Harvard Business Review, 73(2), 80-88.

Skyrius, R., \& Bujauskas, V. (2010). A study on complex information needs in business activities. Informing Science: The International Journal of an Emerging Transdiscipline, 13, 1-13. Retrieved from http://www.inform.nu/Articles/Vol13/ISJv13p001-013Skyrius550.pdf

Stewart, R. (1999). Some observations concerning Sayles' managerial behaviour. Leadership Quarterly, 10(1), 17-20.

Södergren, B., \& Söderholm, J. (2001). Managing positions or people? In S-E. Sjöstrand, J. Sandberg, \& M. Tyrstrup (Eds.), Invisible management: The social construction of leadership (pp. 240- 257). Mitcham: Thomson Learning.

Tengblad, S. (2000). Executive behaviour revisited: Perspectives on a classical work within management research. Göteborg: GRI.

van der Veeken, H., \& Wouters, M. (2002). Using accounting information systems by operations managers in a project company. Management Accounting Research, 13(3), 345-370.

Walsham, G. (1995). Interpretive case studies in IS research: Nature and method. European Journal of Information Systems, 4(2), 74-81. 
Weick, K. (1985). Cosmos vs. chaos: Sense and nonsense in electronic contexts. Organizational Dynamics, 14(2), 51-64.

Weick, K. (1995). Sensemaking in organizations. Thousand Oaks, CA: Sage.

Westelius, A. (1996). A study of patterns of communication in management accounting and control projects. Stockholm: EFI.

Zimmerman, J.L. (2001). Conjectures regarding empirical managerial accounting research. Journal of Accounting and Economics, 32(1-3), 411-427.

\section{Appendix: Main Conclusions}

\begin{tabular}{|c|c|}
\hline Main points & Positions expressed by the interviewees \\
\hline $\begin{array}{l}\text { Soft information and personal meetings } \\
\text { important in the information mosaic }\end{array}$ & $\begin{array}{l}\text { 'Generally, I need information about people, from } \\
\text { people. It is important to listen in order to obtain a } \\
\text { sense of needs and problems.' (Administrative man- } \\
\text { ager) } \\
\text { 'It is important for me to know how my subordinates } \\
\text { feel, so that I know how to act towards them, so that I } \\
\text { do not put unnecessary pressure on them if they have } \\
\text { problems in their private life. It is also important to } \\
\text { know their opinions about my work, so that I can im- } \\
\text { prove as a manager.' (Operations manager) } \\
\text { 'I need information that comes from the individual } \\
\text { himself/herself. It is important to have an open dia- } \\
\text { logue about what they want to do at work.' (Section } \\
\text { manager) }\end{array}$ \\
\hline $\begin{array}{l}\text { Complementarity of formal and informal } \\
\text { sources of information, and the role of } \\
\text { pre-understanding in making sense of } \\
\text { information }\end{array}$ & $\begin{array}{l}\text { 'The administrative system is not fully reliable. Some } \\
\text { manual work is usually required, for example I may } \\
\text { have to speak to the programme administrator in or- } \\
\text { der to get a more accurate picture.' (Programme } \\
\text { manager) } \\
\text { 'Relating financial information to real life events re- } \\
\text { quires a thorough understanding of the business. I use } \\
\text { a broad network of people in order to grasp the prob- } \\
\text { lem.' (Project manager) }\end{array}$ \\
\hline $\begin{array}{l}\text { Lack of information rarely related to for- } \\
\text { mal information systems }\end{array}$ & $\begin{array}{l}\text { 'I would like more continuous information from } \\
\text { those who negotiate with the clients so that I could } \\
\text { more easily plan the allocation of resources.' (Section } \\
\text { manager) } \\
\text { 'I would love more information from the manage- } \\
\text { ment about where we are heading; it would be nice to } \\
\text { know more about the future so that we do not have to } \\
\text { deny and redo things' (Team leader) } \\
\text { 'One could say that I need a fortune-teller; I want soft } \\
\text { information about what is going on, about the com- } \\
\text { petitive situation, what the EU intends to do, and so } \\
\text { on.' (CEO) }\end{array}$ \\
\hline
\end{tabular}




\begin{tabular}{|l|l|}
\hline $\begin{array}{l}\text { Different categories of management and } \\
\text { use of information require different in- } \\
\text { formation behaviour }\end{array}$ & $\begin{array}{l}\text { 'The teachers could come up with suggestions on } \\
\text { what they need, but there is not much of a discussion } \\
\text { in the budgetary work because there are no funds.' } \\
\text { (Municipal headmistress) }\end{array}$ \\
& $\begin{array}{l}\text { 'Information used to be rather aggregated, but now I } \\
\text { have created a scorecard for each store in order to } \\
\text { increase cost awareness.' (Project manager) } \\
\text { 'I try to walk around and have them talking, I think } \\
\text { that most subordinates like that their manager is visi- } \\
\text { ble. I also think that they appreciate being asked for } \\
\text { information by their supervisor, they are happy that } \\
\text { someone is interested in how they can contribute.' } \\
\text { (Section manager) } \\
\text { 'I prefer talking to my subordinates face-to-face be- } \\
\text { cause I believe that it is important to show them that I } \\
\text { see them. And it is important not only to approach } \\
\text { subordinates in specific matters but also in other } \\
\text { situations, in order to keep in touch.' (Environmental } \\
\text { department manager) }\end{array}$ \\
\hline
\end{tabular}

\section{Biographies}

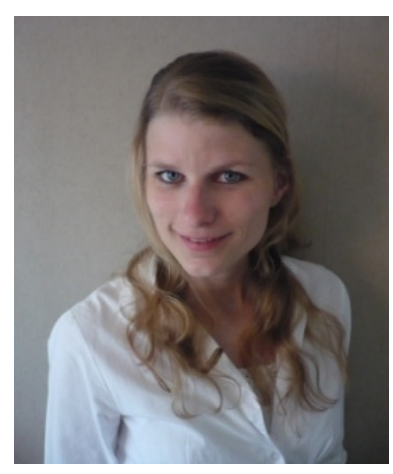

Cecilia Gullberg is a Ph. D. student at the Department of Management and Engineering at the Linköping University, Sweden. She is also associated with the Swedish Research School of Management and Information Technology. Her research interests include management control and the use of information in managerial roles. She is also teaching courses in organisational theory, management control and the use of ERP systems.

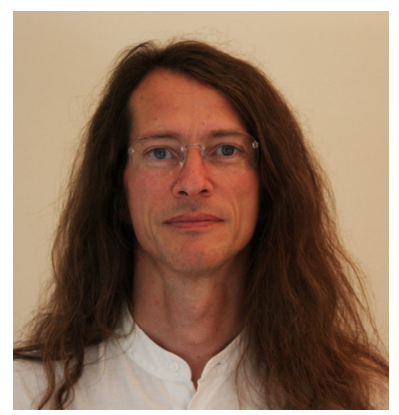

Alf Westelius is a professor of Economic Information Systems at the Linköping University, Sweden, and consultant to private, public and non-profit organisations. His research centres on change processes and conditions for attaining sustainable change. Related areas include strategic applications of IT, learning, knowledge management, and management control. The concept Perspectives management - identifying and paying heed to perspective differences among people regarding the phenomenon of interest - is central in his research. 